"Exploring supply chain management practices within municipalities in the West Rand district"

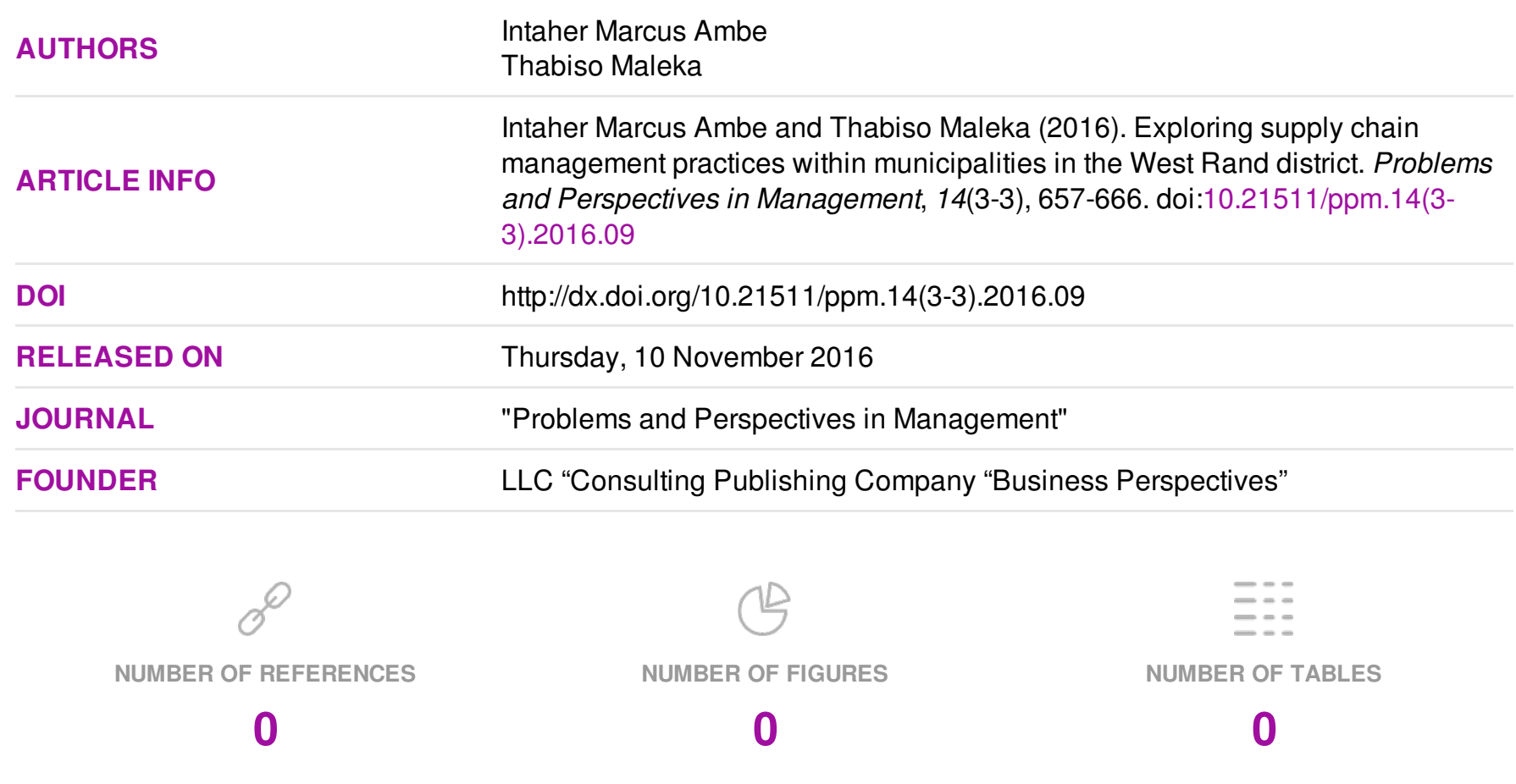

(C) The author(s) 2022. This publication is an open access article. 
Intaher Marcus Ambe (South Africa), Thabiso Maleka (South Africa)

\title{
Exploring supply chain management practices within municipalities in the West Rand district
}

\begin{abstract}
This article explores supply chain management practices within selected municipalities in the West Rand district, Gauteng. An empirical research was conducted among supply chain practitioners in the municipalities based on the purposive sampling technique and the data were analyzed using descriptive statistics. The findings revealed that the municipalities have adopted and implemented supply chain management practices. However, supply chain management objectives are not always appropriately aligned with government policies, and the municipalities face serious supply chain issues such as leadership, lack of proper accountability and good governance. From the findings, it is evident that the lack of proper implementation of supply chain management in municipalities is the root cause of problems in service delivery in South Africa. It is recommended that municipal supply chain officials be empowered with supply chain skills for proper supply chain management execution.
\end{abstract}

Keywords: supply chain, municipalities, practices, West Rand district.

JEL Classification: M11.

\section{Introduction}

Despite reform processes in the employment of supply chain management (SCM) as a strategic tool in the South African public sector, there are predicaments in SCM practices, especially in municipalities. SCM is an important concept in today's business environment, as it contributes significantly to the bottom line (Agus, 2011, p. 269). SCM has received significant attention across different business industries and sectors (Naudé and Badenhorst-Weiss, 2011, p. 71). According to Arlbjørn, Freytag and De Haas (2010, p. 277), SCM is a proven business strategy that has gained wide acceptance in recent years due to the increasing customer demands for quality, delivery and speed. Increased speeds of communicating coupled with cost reduction and more independent suppliers, provider and customer relationships have accelerated the integration of supply chains on a widespread basis (Malhan, 2015, p. 21).

In South Africa, SCM is an integral part of the South African public sector financial management. According to the South African National Treasury (NT) (NT, 2005), the concept of SCM was adopted in 2003 due to deficiencies in the public procurement processes (previously known as the tender board system). Procurement reform processes in the South African public sector were initiated and directed at the promotion of principles of good governance, and the introduction of a preference system to address socioeconomic objectives (Ngobeni, 2011, p. 29). However, the system resulted in a lack of accountability, and improper application and

(C) Intaher Marcus Ambe, Thabiso Maleka, 2016.

Intaher Marcus Ambe, Department of Entrepreneurship, Supply Chain, Transport, Logistics \& Tourism, University of South Africa, South Africa.

Thabiso Maleka, Department of Entrepreneurship, Supply Chain, Transport, Logistics \& Tourism, University of South Africa, South Africa. implementation of the Preferential Procurement Policy Framework Act (PPPFA) (Wall, Watermeyer and Pirie, 2012, p. 1).

The purpose of the adoption of SCM in the South African public sector was to introduce internationally accepted best procurement practice principles, while at the same time addressing government's preferential procurement policy objectives (Office of Government of Commerce (OGC), 2005). SCM is aimed at adding value at each stage of the procurement process, from the demand of goods or services to their acquisition, managing the logistics process and finally, after use, to their disposal (Ambe and Badenhorst-Weiss, 2012, p. 244). In doing so, it needs to address deficiencies in current practices related to procurement, contract management, inventory and asset control, and obsolescence planning (NT, 2003; Mkhize, 2004). Mnguni (2012, p. 49) asserted that policies governing SCM implementation across all spheres of government were developed. Each government entity had to adopt the SCM policy to suit its needs (NT, 2015, p. 1). By virtue of the adoption of SCM practices in the South African public sector, as well as national and provincial departments, local government (municipalities), as well as parastatals are expected to implement SCM efficiently and effectively to ensure good governance, preference and the socioeconomic objectives of the country.

Notwithstanding the adoption of SCM policies and practices across all spheres of government, its implementation remains a challenge, especially in local government. This is evidenced by daily reports of irregularities in newspapers, television, radio and social media. A report by the Auditor General of South Africa (AG) (AG, 2015) highlights the fact that municipalities are still facing challenges of noncompliance and irregular expenditure. The municipal audit report showed that in the 2012-13 financial year, 
irregular expenditures of R11437 million were reported. The Auditor General Report (2012) indicated that R141 million worth of contracts were awarded to suppliers in which family members of employees had an interest. Seen in this light, this article explores SCM practices to determine if the West Rand district municipalities have fully implemented SCM and are practising SCM, as required by the National Treasury.

This article is of utmost importance, as it gives an understanding of SCM practice within the West Rand district municipalities; it also contributes to increasing the body of knowledge in the field of SCM, especially compliance in local and district municipalities. The remaining sections of the article discuss a review of SCM practices, the research methodology that is employed in the study, the findings, and the conclusions.

\section{Review of supply chain management practices}

This section presents a contextualization of what necessitated the study. The section begins with an overview of SCM; SCM in the South African public sector; a review of the West Rand district municipalities; and the challenges of SCM in municipalities.

\subsection{Background to supply chain management.} Supply chain management (SCM) is a term used in business literature to refer to the control of materials, information and finances, as they move in a process from supplier to manufacturer to wholesaler to retailer, and, ultimately, to the consumer (Chopra and Meindl, 2013, p. 13). The term "supply chain" is inspired by the product flow that should be delivered to citizens or businesses, as it passes through several organizations. The main objective of SCM is to satisfy end users and increase profitability for the organization (Peng, Lawrence, Snyder, Lim and Liu, 2011, p. 1).

According to the Council of Supply Chain Management Professionals (CSCMP, 2007), "Supply chain management encompasses the planning and management of all activities involved in sourcing and procurement, conversion, and all logistics management activities. It also includes coordination and collaboration with channel partners, which can be suppliers, intermediaries, third party service providers, and customers". In a functional sense, this focus on activities and relationships implies that logistics, marketing, purchasing/supply, and production/operations are involved in SCM.

The Institution for Supply Chain Management (2014) defines SCM as the identification, acquisition, access, positioning and management of resources and related capabilities that an organization requires or potentially desires in the achievement of strategic objectives. SCM is an integrating function with the primary responsibility for linking major business functions and business processes within and across companies into a cohesive and high-performing business model. It includes all the logistics management activities, as well as manufacturing operations, and it drives the coordination of processes and activities, with and across marketing, sales, product design, and finance and information technology (Hugo, Badenhorst and Van Biljon, 2006, p. 8). Lambert (2006, p. 3) asserted that SCM is the management of relationships in the network of organizations, from end customers through to original suppliers, using the core cross-functional business processes to create value for customers and other related stakeholders. Therefore, SCM encompasses the planning and management of all the activities involved in sourcing and procurement, conversion, and all logistics management activities. Importantly, it also includes coordination and collaboration with channel partners, which can be suppliers, intermediaries, third party service providers and customers.

1.2. Supply chain management in South African municipalities. The South African public sector supply chain has undergone transformation through the introduction of procurement reforms. The procurement reforms started in 1995 and were directed at the promotion of the principles of good governance and the introduction of a preference system to address certain socioeconomic objectives. SCM was introduced in the South African public sector as a measure to alleviate the deficiencies of the previous tender board system, and with the objective of achieving good governance and economic development (Mkhize, 2004, p. 5). The SCM process is guided by policies and regulations. The National Treasury developed an SCM policy that was to be adopted by all government entities to suit their needs. Based on the adoption of SCM, the various spheres of government had to adopt the policy to suit their needs, and to give considerations to relevant legislations and regulations guided by the SCM business model.

1.2.1. Supply chain management policy. Preceding the introduction of SCM, a SCM document titled "Policy to guide uniformity in procurement reform processes in government" was developed in conjunction with Provincial Treasuries to replace the outdated procurement and provisional practices in municipal entities (NT, 2007). In 2005, "Supply chain management: a guide for accounting officers of municipalities and municipal entities" was developed to give guidance on the adoption of the integrated SCM function and the related managerial responsibilities assigned to accounting officers in terms of Sections 62 and 95 of the Municipal Finance Management Act (MFMA). The guide explains how Chapter 11, Part 1 of the MFMA, the municipal SCM regulations, and the SCM policy of the council or board of directors can be adopted into an operational 
process for accounting officers at each step of the SCM cycle. The principle behind the policy guide is based on the fact that managers should be given the flexibility to manage within a framework that satisfies the constitutional requirements of transparency and accountability (NT, 2005, p. 9).

1.2.2. Legislation governing SCM. The SCM processes and activities of municipalities today are multifaceted. As a result, supply chain policies are complex and impact significantly on the smooth functioning of the municipality and its competitive position (Ngobeni, 2011). Numerous variables and a large body of information influence SCM policy-making. Without a legislative framework, political representatives will not be able to make informed and intelligent decisions. SCM is governed and guided by a number of legislative requirements.

1.2.3. The SCM business model. According to the SCM guide for accounting officers, SCM in the South African public sector is guided by the SCM model. The model consists of six elements of SCM, namely, demand management, acquisition management, logistics management, disposal management, risk management and performance evaluation (Mnguni, 2012). Figure 1 presents the SCM business model.

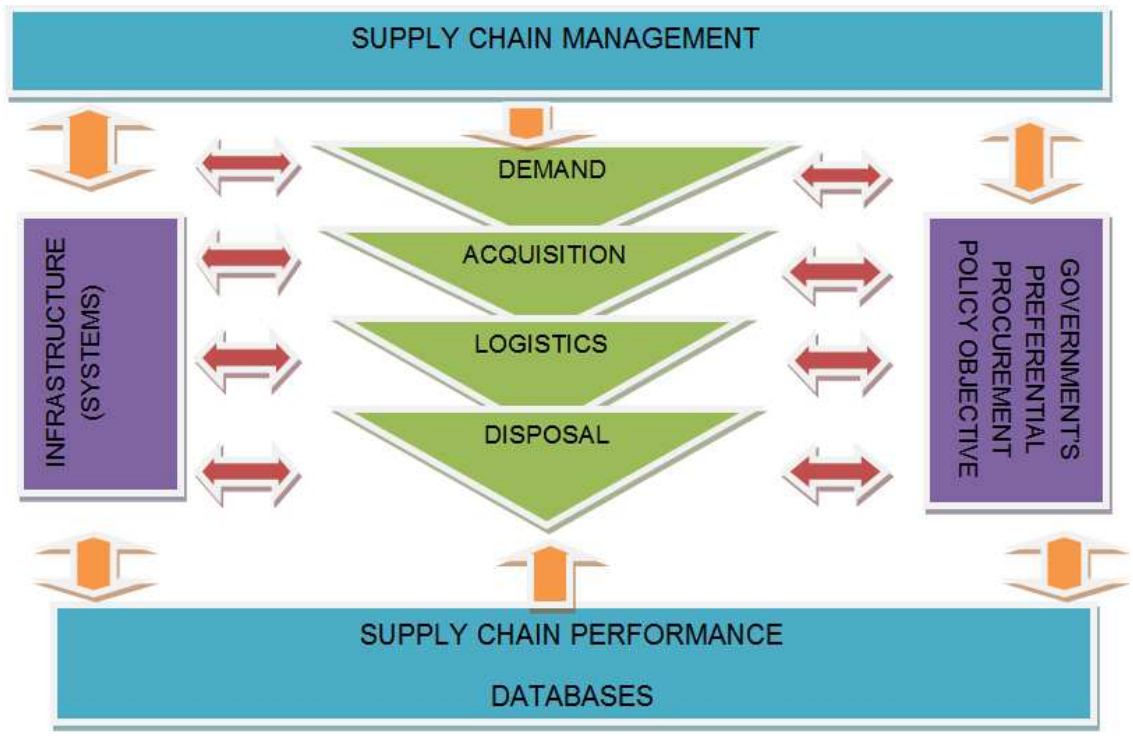

Fig. 1. Supply chain management business model

Source: National Treasury (2004, p. 10).

The six elements of SCM are briefly discussed below (NT, 2005):

- Demand management: This is the first element of SCM. It is aimed at fulfilling the needs identified during the strategic planning process. The total needs assessment should be undertaken before the process can start. Resources required must be analyzed and assessed, and key elements in the demand management process should be considered and should bring the SCM practitioner closer to the end users.

- Acquisition management: The management of procurement includes the evaluation of bids, the composition of bid committees, the compilation of a register for defaulters, the range of procurement systems, the establishment of total cost of ownership of assets, bid adjudication, and the appointment of consultants.

- Logistics management: This means to strategically manage acquisition, the movement and storage of materials, the cost fulfilment of orders, and to ensure the effective flow of goods, services and related information from the point of origin to the point of consumption.

- Disposal management: The management of assets that are no longer needed gave rise to the need for obsolescence planning, which means the creation of a database of redundant materials, the inspection of materials for re-use, and determining the disposal strategy and methods of execution.

- Risk management: This refers to the management of unintended or unexpected outcomes of a decision and makes provision for identifying, considering and avoiding risk, as well as the provision for adequate cover for residual risks.

- Supply chain performance: This monitors the progress undertaken in a retrospective analysis to determine whether the processes have been followed and if the desired objectives were achieved. The National Treasury template for measuring performance is used. 
These elements are the basis on which an efficient SCM system is implemented across all spheres of government, including municipalities.

1.2.4. Review of West Rand district municipalities. The structure of local government is dealt with in terms of the Municipal Structures Act 117 of 1998, which sets out the categories and types of municipalities and provides for elections and other matters. The Constitution provides for three categories of municipalities. These are Category A (metropolitan), Category B (district) and Category C (local). There are 278 municipalities in South Africa, comprising 8 metropolitan, 44 district and 226 local municipalities (EM, 2015). District municipalities are made up of a number of local municipalities that fall under one district. Typically, there are between 4 and 6 local municipalities that fall under one district council (SA Yearbook, 2014/5).

West Rand district municipality (WRDM) is one of the 44 district municipalities in South Africa. The headquarters of the municipality is located in Randfontein on the south-western border of Gauteng Province. WRDM is placed under Category B (district municipalities) and comprises four local municipalities, namely Randfontein Local Municipality, Merafong Local Municipality, Mogale Local Municipality and Westonia Local Municipality. Table 1 shows the composition of the West Rand district municipality, including the four local municipalities that reside under it.

Table 1. Composition of West Rand district municipalities and their population profile

\begin{tabular}{|l|c|c|c|}
\hline Municipality & Population & $\begin{array}{c}\text { Number of } \\
\text { households }\end{array}$ & $\begin{array}{c}\text { Average household } \\
\text { size }\end{array}$ \\
\hline Westonia & 109324 & 288334 & 2.85 \\
\hline Merafong & 46053 & 111767 & 2.43 \\
\hline Mogale City & 362422 & 123398 & 2.94 \\
\hline Randfontein & 149286 & 48455 & 3.08 \\
\hline
\end{tabular}

Source: Census (2011).

\section{Research methodology}

The purpose of this article is to explore SCM practices in the West Rand district municipality based on an empirical study. An empirical study involves drawing conclusions based on observations, experiments or experiences from an investigation (Quinlan, 2011, p. 12). The article is exploratory in nature, and the research strategy was a case study. A case study can be defined as a process or record of research into the development of a particular person, group or situation over a period of time (West, 2016). A case study was the preferred research strategy, because it provided occurrences of existing SCM cases in the West Rand district municipalities and it provided the researcher with the opportunity to compare and evaluate SCM practices in all the municipalities in the West Rand district.

The targeted population of the study constitutes municipalities in the West Rand district (Randfontein Local Municipality, Westonaria Local Municipality, Mogale City Local Municipality, Merafong City Local Municipality and Westonia Local Municipality). Purposive sampling as a non-probability sampling technique was used in the study. The basic criteria for selecting the respondents were based on the seniority of their position and their possession of expert knowledge of SCM practices. The data for the study were collected through face-to-face interviews based on a semi-structured questionnaire measured using a 5 Likert-scale response format with an ordinal scale ranging from 1 (no extent), 2 (slight extent), 3 (moderate extent), 4 (large extent) and 5 (very large extent). A total of 15 respondents who constitute SCM managers and practitioners were interviewed. The data collected (quantitative data for the purpose of this article) were analyzed descriptively using a Statistical Package for Social Sciences (SPSS).

\section{Findings and discussion}

This section of the article presents the findings with regard to SCM practices in the municipalities. Respondents were asked to indicate their agreement from 1 (no extent) to 5 (very large extent) on the statement relating to demand management, acquisition management, logistics management, disposal management, risk management, supply chain performance, and supply chain challenges.

3.1. Demand management. The respondents were asked to indicate their level of agreement to nine statements regarding demand management practices in their municipalities. The statements were measured using a 5-point Likert scale format (where $1=$ no extent, $2=$ slight extent, $3=$ moderate extent, $4=$ large extent, and $5=$ very large extent). Table 2 shows the perceptions of the respondents regarding demand management measured in percentages. Table 3 shows the description of the statements used in Table 2. 
Table 2. Perception of respondents regarding demand management practices measured in percentages

\begin{tabular}{|l|c|c|c|c|c|c|c|c|c|c|c|c|}
\hline \multirow{2}{*}{ Statements } & \multicolumn{2}{|c|}{ No extent } & \multicolumn{2}{c|}{ Slight extent } & \multicolumn{2}{c|}{ Moderate extent } & \multicolumn{2}{c|}{ Large extent } & \multicolumn{2}{c|}{ Very large extent } & \multicolumn{2}{c|}{ Total } \\
\cline { 2 - 16 } & $\mathrm{N}$ & $\%$ & $\mathrm{~N}$ & $\%$ & $\mathrm{~N}$ & $\%$ & $\mathrm{~N}$ & $\%$ & $\mathrm{~N}$ & $\%$ & $\mathrm{~N}$ & $\%$ \\
\hline B4-1 & - & - & 1 & 6.7 & 3 & 20 & 5 & 33.3 & 6 & 40 & 15 & 100 \\
\hline B4-2 & 1 & 6.7 & - & - & 3 & 20 & 4 & 26.7 & 7 & 46.7 & 15 & 100 \\
\hline B4-3 & 2 & 13.3 & 3 & 20 & 2 & 13.3 & 4 & 26.7 & 4 & 26.7 & 15 & 100 \\
\hline B4-4 & 1 & 6.7 & 1 & 6.7 & 1 & 6.7 & 3 & 20 & 9 & 60 & 15 & 100 \\
\hline B4-5 & - & - & 1 & 6.7 & 1 & 6.7 & 6 & 40 & 7 & 46.7 & 15 & 100 \\
\hline B4-6 & - & - & 1 & 6.7 & 2 & 13.3 & 4 & 26.7 & 8 & 53.3 & 15 & 100 \\
\hline B4-7 & 2 & 13.3 & 3 & 20 & 5 & 33.3 & 3 & 20 & 2 & 13.3 & 15 & 100 \\
\hline B4-8 & 1 & 6.7 & 1 & 6.7 & 10 & 66.7 & 3 & 20 & - & - & 15 & 100 \\
\hline B4-9 & 2 & 13.3 & 1 & 6.7 & 7 & 46.7 & 3 & 20 & 2 & 13.3 & 15 & 100 \\
\hline
\end{tabular}

Table 3. Description of statements used in Table 2 relating to demand management

\begin{tabular}{|l|l|}
\hline \multicolumn{1}{|c|}{ Quotes } & \\
\hline B4-1 & Our specifications for bid documents are always correct \\
\hline B4-2 & All our purchases were budgeted for \\
\hline B4-3 & We always analyze the market before sending out bids \\
\hline B4-4 & We have procurement plans in place by different departments \\
\hline B4-5 & We effectively utilize our bid register \\
\hline B4-6 & We procure based on integrated development plan (IDP) \\
\hline B4-7 & We conduct spent analysis of previous years \\
\hline B4-8 & Our suppliers always adhere to delivery dates \\
\hline B4-9 & User departments always submit procurement plans (PPs) in time \\
\hline
\end{tabular}

Source: questionnaire.

In terms of the perception of the respondents on demand management, Table 2 indicates that on average, $73 \%$ of the respondents agree to a large extent or very large extent with the statements relating to the correct use of demand management practices.

The highest category of agreement was with the statements relating to the effective use of the bid register (B4-5 with 87\%). This was followed by the importance of procurement plans and procurement based in IDP (B4-4 and B4-6, respectively, with $80 \%$ ). The third highest category of agreement was with the statement on the purchases that were budgeted for (B4-2 with 73\%). The fourth was with the statement linked to specifications and bid documents (B4-1 with 70\%), and the fifth was with the statement relating to the analysis of the market before sending out bids (B4-3 with 53.4\%).

Moreover, Table 2 reveals that $50 \%$ of the respondents moderately agreed with the statements relating to suppliers' adherence to delivery dates (B4-8 with $66.7 \%$ ). The lowest category of agreement was with the user department submission of PPs on time (B4-9 with $46.7 \%$ ). This was followed by agreement with the statement relating to conducting a spent analysis of the previous years (B4-7 with 33.3\%).
Table 2 stipulates that more than $20 \%$ of the respondents agree (slight extent) with the statement relating to an analysis of the market before sending out bids (B4-3) and they slightly think that municipalities are conducting a spent analysis of the previous years. The results as reflected in Table 2 show that less than $10 \%$ of the respondents agree to a slight extent with the statements relating to specification and bid document (B4-1), procurement plans in place (B4-4), the effective use of the bid register (B4-5), procurements are based on IDP (B4-6), suppliers always adhere to delivery dates (B4-4), and users who always submit PPs on time.

3.2. Acquisition management. Participants were asked to indicate the extent to which they agree with the statement relating to acquisition management practices in their respective municipalities. The statements were measured using a 5-point Likert scale format (where $1=$ no extent, 2 = slight extent, 3 = moderate extent, $4=$ large extent, and $5=$ very large extent). Table 4 shows (in percentages) the perception of the respondents regarding the acquisition management practices measured. Table 5 shows the description of the statements used in Table 4.

Table 4. Perception of the respondents on the statement regarding acquisition management

\begin{tabular}{|c|c|c|c|c|c|c|c|c|c|c|c|c|}
\hline \multirow{2}{*}{ Statements } & \multicolumn{2}{|c|}{ No extent } & \multicolumn{2}{|c|}{ Slight extent } & \multicolumn{2}{|c|}{ Moderate extent } & \multicolumn{2}{|c|}{ Large extent } & \multicolumn{2}{|c|}{ Very large extent } & \multicolumn{2}{|c|}{ Total } \\
\hline & $\mathrm{N}$ & $\%$ & $\mathrm{~N}$ & $\%$ & $\mathrm{~N}$ & $\%$ & $\mathrm{~N}$ & $\%$ & $\mathrm{~N}$ & $\%$ & $\mathrm{~N}$ & $\%$ \\
\hline B5-1 & - & - & - & - & 3 & 20 & 6 & 40 & 6 & 60 & 15 & 100 \\
\hline
\end{tabular}


Table 4 (cont.). Perception of the respondents on the statement regarding acquisition management

\begin{tabular}{|l|c|c|c|c|c|c|c|c|c|c|c|c|}
\hline \multirow{2}{*}{ Statements } & \multicolumn{2}{|c|}{ No extent } & \multicolumn{2}{c|}{ Slight extent } & \multicolumn{2}{c|}{ Moderate extent } & \multicolumn{2}{c|}{ Large extent } & \multicolumn{2}{c|}{ Very large extent } & \multicolumn{2}{c|}{ Total } \\
\cline { 2 - 16 } & $\mathrm{N}$ & $\%$ & $\mathrm{~N}$ & $\%$ & $\mathrm{~N}$ & $\%$ & $\mathrm{~N}$ & $\%$ & $\mathrm{~N}$ & $\%$ & $\mathrm{~N}$ & $\%$ \\
\hline B5-2 & - & - & 1 & 6.7 & 1 & 6.7 & 3 & 20 & 10 & 66.7 & 15 & 100 \\
\hline B5-3 & 1 & 6.7 & - & - & 2 & 13.3 & 5 & 33.3 & 7 & 46.7 & 15 & 100 \\
\hline B5-4 & - & - & 1 & 6.7 & - & - & 2 & 13.3 & 12 & 80 & 15 & 100 \\
\hline B5-5 & - & - & - & - & 4 & 26.7 & 3 & 20 & 8 & 53.3 & 15 & 100 \\
\hline B5-6 & 3 & 20 & 3 & 20 & 1 & 6.7 & 5 & 33.3 & 3 & 20 & 15 & 100 \\
\hline B5-7 & 8 & 53.3 & 1 & 6.7 & 4 & 26.7 & 1 & 6.7 & 1 & 6.7 & 15 & 100 \\
\hline B5-8 & - & - & - & - & 1 & 6.7 & 2 & 13.3 & 12 & 80 & 15 & 100 \\
\hline B5-9 & - & - & - & - & 1 & 6.7 & 1 & 6.7 & 13 & 86.7 & 15 & 100 \\
\hline B5-10 & 2 & 13.3 & 4 & 26.7 & 6 & 40 & - & - & 3 & 20 & 15 & 100 \\
\hline B5-11 & 15 & 100 & - & - & - & - & - & - & - & - & 15 & 100 \\
\hline B5-12 & 11 & 73.3 & 2 & 13.3 & 2 & 13.3 & - & - & - & - & 15 & 100 \\
\hline
\end{tabular}

Table 5. Description of statements used in Table 4 relating to acquisition management practices

\begin{tabular}{|l|l|}
\hline \multicolumn{1}{|c|}{ Statements } & \\
\hline B5-1 & We have effective sourcing strategies \\
\hline B5-2 & Supplier database updated annually \\
\hline B5-3 & All verbal quotes followed up with written quotes \\
\hline B5-4 & All suppliers in database have signed vendor forms \\
\hline B5-5 & We have appropriate control of SCM data \\
\hline B5-6 & Adequate control in place to prevent splitting of orders \\
\hline B5-7 & There is favoritism for suppliers' selection for written quotations \\
\hline B5-8 & We use competitive bidding for amounts exceeding R200 000 \\
\hline B5-9 & Bid document always indicates 80/20 or 90/10 preference points \\
\hline B5-10 & SCM powers and duties are verbally delegated \\
\hline B5-11 & We sometimes consider late bids \\
\hline B5-12 & Bid committee members do not understand their functions \\
\hline
\end{tabular}

Source: questionnaire.

In relation to Table 4, the results show that $100 \%$ of the respondents agree (large extent or very large extent) with statements relating to effective sourcing strategies (B5-1). This is followed by statements relating to bid documents always indicating $80 / 20$ or 90/10 preferred points (B5-9 with 93.4\%). Next were the statements relating to suppliers having a signed vendor form and the use of competitive bidding for exceeding amount (B5-4 and B5-8 with 93.3\% each). The fourth highest response was to the statement relating to the updating of the supplier database (B4-2 with 86.7\%). This was followed by the statement relating to verbal quotes followed by written quotes (B5-3 with 80\%). The sixth highest percentage was related to the statement on control to prevent the splitting of orders (B5-6 with 73.3\%).

In terms of the perception of the respondents on acquisition management, Table 4 indicates that on average, $58.8 \%$ of the respondents agree to a large extent or very large extent with the statements relating to acquisition management practices. The results in Table 4 further indicate that on average, less than $15 \%$ of the respondents agree moderately with the statement relating to SCM powers and duties that are verbally delegated (B5-10). The results also show that on average, less than $30 \%$ of the respondents disagree (no extent or slight extent) with the statement relating to late bids that are considered (B5-11). This was followed by the statement relating to bid committee members who do not understand their function (B5-12 with 73.3\%).

3.3. Logistic management. When it comes to logistic management, the respondents were asked to indicate their level of agreement with 12 statements related to logistic management practices ranging from 1 (no extent) to 5 (very large extent). Table 6 (which follows) presents the perceptions of respondents expressed in percentages and Table 7 presents the description of the statements used in Table 6.

Table 6. Perception of respondents on statements relating to logistic management

\begin{tabular}{|c|c|c|c|c|c|c|c|c|c|c|c|c|}
\hline \multirow{2}{*}{ Statements } & \multicolumn{2}{|c|}{ No extent } & \multicolumn{2}{|c|}{ Slight extent } & \multicolumn{2}{|c|}{ Moderate extent } & \multicolumn{2}{|c|}{ Large extent } & \multicolumn{2}{|c|}{ Very large extent } & \multicolumn{2}{|c|}{ Total } \\
\hline & $\mathrm{N}$ & $\%$ & $\mathrm{~N}$ & $\%$ & $\mathrm{~N}$ & $\%$ & $\mathrm{~N}$ & $\%$ & $\mathrm{~N}$ & $\%$ & $\mathrm{~N}$ & $\%$ \\
\hline B6-1 & - & - & 1 & 6.6 & 3 & 20 & 7 & 46.7 & 4 & 26.7 & 15 & 100 \\
\hline B6-2 & - & - & 1 & 6.7 & 2 & 13.3 & 5 & 33.3 & 7 & 46.7 & 15 & 100 \\
\hline
\end{tabular}


Table 6 (cont.). Perception of respondents on statements relating to logistic management

\begin{tabular}{|c|c|c|c|c|c|c|c|c|c|c|c|c|}
\hline \multirow{2}{*}{ Statements } & \multicolumn{2}{|c|}{ No extent } & \multicolumn{2}{|c|}{ Slight extent } & \multicolumn{2}{|c|}{ Moderate extent } & \multicolumn{2}{|c|}{ Large extent } & \multicolumn{2}{|c|}{ Very large extent } & \multicolumn{2}{|c|}{ Total } \\
\hline & $\mathrm{N}$ & $\%$ & $N$ & $\%$ & $\mathrm{~N}$ & $\%$ & $\mathrm{~N}$ & $\%$ & $\mathrm{~N}$ & $\%$ & $N$ & $\%$ \\
\hline B6-3 & 3 & 20 & 1 & 6.7 & 6 & 40 & 5 & 33.3 & - & - & 15 & 100 \\
\hline $\mathrm{B} 6-4$ & 5 & 33.3 & 1 & 6.7 & 6 & 40 & 1 & 6.7 & 2 & 13.3 & 15 & 100 \\
\hline B6-5 & 9 & 60 & 1 & 6.7 & 4 & 26.6 & - & - & 1 & 6.7 & 15 & 100 \\
\hline $\mathrm{B} 6-6$ & - & - & 1 & 6.7 & 8 & 53.3 & 3 & 20 & 3 & 20 & 15 & 100 \\
\hline B6-7 & 2 & 13.3 & 2 & 13.3 & 4 & 26.7 & 2 & 13.3 & 5 & 33.3 & 15 & 100 \\
\hline B6-8 & 3 & 20 & 2 & 13.3 & 4 & 26.7 & - & - & 6 & 40 & 15 & 100 \\
\hline
\end{tabular}

Table 7. Description of statements in Table 6 relating to logistic management

\begin{tabular}{|l|l|}
\hline \multicolumn{1}{|c|}{ Statements } & \\
\hline B6-1 & We have effective warehouse management \\
\hline B6-2 & All stock items are distributed from warehouse \\
\hline B6-3 & Transport management has updated log books \\
\hline B6-4 & Stock levels are replenished monthly \\
\hline B6-5 & Orders are placed once a month \\
\hline B6-6 & We have appropriate procedure manuals \\
\hline B6-7 & Adequate control in place to prevent theft of stock \\
\hline B6-8 & End-user and SCM officials identify stock during deliveries \\
\hline
\end{tabular}

Source: questionnaire.

In terms of the perceptions of the respondents on logistic management, Table 6 indicates that on average, $42.5 \%$ of the respondents agree to a large extent or very large extent with the statements relating to logistic management practices. The highest responses were to the statement relating to the distribution of items from the warehouse (B6-2 with $80 \%)$. This was followed by the statement relating to effective management of the warehouse (B6-1 with $73.4 \%$ ). The lowest category of responses was to the statements relating to adequate control to prevent theft of stock (B6-7 with 46.6\%). This was followed by the statements relating to appropriate manual procedures and official identification of stock during deliveries (B6-6 and B6-8 with 40\%).

The results in Table 6 further indicate that on average, less than $32 \%$ of the respondents agree to a moderate extent with the statements relating to logistic management practices. The highest acceptance was with the statement related to correct manual procedures (B6-6 with 53.3\%). This was followed by the statements relating to transport management having an updated log book and stock levels that are replenished monthly (B6-3 and B6-4 with 40\% each). Moreover, the results in Table 6 further show that on average, $28 \%$ of the respondents agree to no extent or a slight extent with the statements relating to logistic management practices. The highest response (no extent) was to the statements relating to orders that are placed once a month (B6-5 with 60\%).

3.4. Disposal management. The respondents were asked to indicate their level of agreement to five statements relating to disposal management practices, ranging from 1 (no extent) to 5 (very large extent). Table 8 presents the perceptions of respondents expressed in percentages, and Table 9 presents the description of the statements used in Table 8.

Table 8. Perceptions of respondents on the statement relating to disposal management

\begin{tabular}{|c|c|c|c|c|c|c|c|c|c|c|c|c|}
\hline \multirow{2}{*}{ Statements } & \multicolumn{2}{|c|}{ No extent } & \multicolumn{2}{|c|}{ Slight extent } & \multicolumn{2}{|c|}{ Moderate extent } & \multicolumn{2}{|c|}{ Large extent } & \multicolumn{2}{|c|}{ Very large extent } & \multicolumn{2}{|c|}{ Total } \\
\hline & $\mathrm{N}$ & $\%$ & $\mathrm{~N}$ & $\%$ & $\mathrm{~N}$ & $\%$ & $\mathrm{~N}$ & $\%$ & $\mathrm{~N}$ & $\%$ & $\mathrm{~N}$ & $\%$ \\
\hline B7-1 & - & - & 4 & 26.7 & 2 & 13.3 & 5 & 33.3 & 4 & 26.7 & 15 & 100 \\
\hline B7-2 & 3 & 20 & 2 & 13.3 & 2 & 13.3 & 6 & 40 & 2 & 13.3 & 15 & 100 \\
\hline B7-3 & 3 & 20 & 3 & 20 & 3 & 20 & 6 & 40 & - & - & 15 & 100 \\
\hline B7-4 & 1 & 6.7 & 4 & 26.7 & 1 & 6.7 & 6 & 40 & 3 & 20 & 15 & 100 \\
\hline B7-5 & 7 & 46.7 & 3 & 20 & 1 & 6.7 & 3 & 20 & 1 & 6.7 & 15 & 100 \\
\hline
\end{tabular}

Table 9. Description of statements in Table 8 relating to disposal management

\begin{tabular}{|l|l|}
\hline Statements & Description of statements \\
\hline B7-1 & Effective assets register available for managing of assets \\
\hline B7-2 & Proper controls available for immovable assets \\
\hline B7-3 & Effective database available for unserviceable items \\
\hline B7- 4 & Availability of asset disposal policy \\
\hline B7-5 & Adequate processes are implemented in disposing of explosives \\
\hline
\end{tabular}

Source: questionnaire. 
As shown in Table 8, the result reveals that on average, $48 \%$ of the respondents agree to a large extent or very large extent with the statements relating to disposal management practices. The highest scores were on the statements relating to effective assets register and the availability of an asset disposal policy (B7-1 and B7-4, respectively, with 60\%). This was followed by the statement linked to the availability of proper controls for immovable assets (B7-2 with $53.3 \%)$. The lowest responses were on the statements relating to a database available for unserviceable items (B7-3 with 40\%).

Moreover, the results indicate that on average, less than $15 \%$ of the respondents agree to a moderate extent with the statements relating to the disposal management variable. Table 8 shows that on average, $40 \%$ of the respondents agree with no extent or slight extent with the disposal management component. The lowest score was related to the statements relating to appropriate processes in the disposal of explosives or obsolete assets (B7-5 with 46.7\%).

3.5. Risk management. The respondents were asked to indicate their level of agreement with five statements relating to risk management practices ranging from 1 (no extent) to 5 (very large extent). Table 10 presents the perceptions of the respondents expressed in percentages and Table 11 presents the description of the statements used in Table 10.

Table 10. Perceptions of the respondents on the statement relating to risk management

\begin{tabular}{|c|c|c|c|c|c|c|c|c|c|c|c|c|}
\hline \multirow{2}{*}{ Statements } & \multicolumn{2}{|c|}{ No extent } & \multicolumn{2}{|c|}{ Slight extent } & \multicolumn{2}{|c|}{ Moderate extent } & \multicolumn{2}{|c|}{ Large extent } & \multicolumn{2}{|c|}{ Very large extent } & \multicolumn{2}{|c|}{ Total } \\
\hline & $\mathrm{N}$ & $\%$ & $\mathrm{~N}$ & $\%$ & $\mathrm{~N}$ & $\%$ & $\mathrm{~N}$ & $\%$ & $\mathrm{~N}$ & $\%$ & $\mathrm{~N}$ & $\%$ \\
\hline B8-1 & 3 & 20 & - & - & 2 & 13.3 & 6 & 40 & 4 & 26.7 & 15 & 100 \\
\hline B8-2 & 1 & 6.7 & 2 & 13.3 & 3 & 20 & 4 & 26.7 & 5 & 33.3 & 15 & 100 \\
\hline B8-3 & - & - & 1 & 6.7 & 5 & 33.3 & 3 & 20 & 6 & 40 & 15 & 100 \\
\hline B8-4 & - & - & - & - & 4 & 26.7 & 5 & 33.3 & 6 & 40 & 15 & 100 \\
\hline B8-5 & 2 & 13.3 & - & - & 6 & 40 & - & - & 7 & 46.7 & 15 & 100 \\
\hline
\end{tabular}

Table 11. Description of statements in Table 10 relating to risk management

\begin{tabular}{|l|l|}
\hline \multicolumn{1}{|c|}{ Statements } & \\
\hline B8-1 & Effective risk management policy \\
\hline B8-2 & Risk management evaluates SCM processes \\
\hline B8-3 & Bid documents are legally sound \\
\hline B8- 4 & Contracts are vetted before tender processes \\
\hline B8-5 & Availability of staff development programs \\
\hline
\end{tabular}

Source: questionnaire.

The findings relating to the risk management practices show that on average, more than $61.3 \%$ agree to a large extent or very large extent with the statements relating to unintended or unexpected outcome of a decision. The highest responses were related to the statements relating to an operational risk management policy (B8-1 with 66.7\%). This was followed by the statements relating to contract and tender processes (B8-4 with 63.3\%). The third highest responses were to the statements relating to the evaluation of the SCM process and bid documents (B8-2 and B8-3 with 60\% each). The lowest scores were to the statements relating to availability or opportunity for staff development (B8-5 with 46.7\%). The findings also revealed that on average, less than $28 \%$ of the respondents agree to a moderate extent with the statements relating to risk management practices. Highest responses were to the statements relating to the contract and tender process (B8-4 with 40\%). The findings indicate that on average, less than $15 \%$ of the respondents agree (no extent or slight extent) with the statements relating to the risk management component.

3.6. Supply chain performance. In this section, respondents were asked to indicate their level of agreement with five statements relating to supply chain performance from 1 (no extent) to 5 (very large extent). Table 12 presents the perceptions of the respondents articulated in percentages. Table 13 presents the description of the statements used in Table 12.

Table 12. Perceptions of the respondents on the statement relating to supply chain performance

\begin{tabular}{|c|c|c|c|c|c|c|c|c|c|c|c|c|}
\hline \multirow{2}{*}{ Statements } & \multicolumn{2}{|c|}{ No extent } & \multicolumn{2}{|c|}{ Slight extent } & \multicolumn{2}{|c|}{ Moderate extent } & \multicolumn{2}{|c|}{ Large extent } & \multicolumn{2}{|c|}{ Very large extent } & \multicolumn{2}{|c|}{ Total } \\
\hline & $\mathrm{N}$ & $\%$ & $\mathrm{~N}$ & $\%$ & $\mathrm{~N}$ & $\%$ & $\mathrm{~N}$ & $\%$ & $\mathrm{~N}$ & $\%$ & $\mathrm{~N}$ & $\%$ \\
\hline B9-1 & 3 & 20 & - & - & 4 & 26.7 & 2 & 13.3 & 6 & 40 & 15 & 100 \\
\hline B9-2 & 7 & 46.7 & 1 & 6.7 & 2 & 13.3 & 3 & 20 & 2 & 13.3 & 15 & 100 \\
\hline B9-3 & 2 & 13.3 & 1 & 6.7 & 1 & 6.7 & 4 & 26.7 & 7 & 46.7 & 15 & 100 \\
\hline B9-4 & - & - & - & - & 2 & 13.3 & 3 & 20 & 10 & 66.7 & 15 & 100 \\
\hline B9-5 & 1 & 6.7 & 1 & 6.7 & 3 & 20 & 3 & 20 & 7 & 46.7 & 15 & 100 \\
\hline
\end{tabular}


Table 13. Description of statements in Table 12 relating to supply chain performance

\begin{tabular}{|l|l|}
\hline \multicolumn{1}{|c|}{ Statements } & \\
\hline B9-1 & Effectively review of achievement of goals \\
\hline B9-2 & Proper procedure manuals for generated savings \\
\hline B9-3 & Effective policies to monitor compliance \\
\hline B9- 4 & SCM objectives are aligned with governments \\
\hline B9-5 & Adequate controls to review SCM performance \\
\hline
\end{tabular}

Source: questionnaire.

Table 12 reflects that on average, more than $62.7 \%$ of the municipalities' respondents are in agreement (to a large extent or very large extent) with the statements relating to supply chain performance practices. The results also revealed that the SCM objectives aligned with government policies, and effective policies to monitor compliance were observed and an adequate control system to review the SCM performance was in place. However, the results showed that a few responses highlighted that there was no proper procedure manual for generating savings in the West Rand district.

Overall the findings indicated that demand management was perceived by all the respondents as the SCM practice they scored the highest in. The findings revealed that on average, more than two thirds of the participants perceived that their municipalities make use of bid registers, procurement based on IDP, procurement plans, that purchases are budgeted for, that there is a specification of bid documents, and that there is an analysis of the market or industry before sending out the bid. These factors positively influence the demand management activities.

The findings highlight that more than half the respondents perceived that there are positive alignments between SCM objectives and government policies, effective compliance monitoring systems, adequate controls for SCM performance review (supply chain performance), effective sourcing strategies, recording of all suppliers, and use of competitive bidding for excessive approach (acquisition management). The findings also suggest that the disposal, logistic and supply chain challenges scored the lowest of all the components of SCM practices.

\section{Conclusions}

This articled explored SCM practices in the West Rand district municipality. SCM is one of the key mechanisms enabling municipalities to implement government policies. As acknowledged in the National Treasury (2015) review, SCM in the South African public sector has been misunderstood and undervalued. An exploratory study was conducted based on a case study in the West Rand district and the findings revealed that the participants agreed that West Rand district municipalities have adopted and implemented SCM practices.

However, SCM practices are not always aligned with government policies. The most implemented SCM practice was demand management, followed by acquisition management. The least implemented practices were logistics, disposal, risk and performance management. No significant difference was observed among the municipalities except for municipality C (within its own supply chain practitioners). The municipalities face serious SCM challenges in implementing their SCM practices. These challenges stem from: lack of training of SCM staff, lack of proper capacity, poor planning, and ineffective black economic empowerment in the West Rand district. Based on the results, there is: a need for training of SCM staff, a lack of proper capacity, poor planning, and ineffective black economic empowerment. It should be reiterated that the lack of proper SCM processes and procedures are the root cause of problems in service delivery in South Africa. The article concludes by recommending that SCM practitioners should regularly update their SCM policy, and ensure proper compliance with the elements of SCM, as well as source competencies, skills, knowledge from higher education institutions and private accredited service providers.

The findings of this article conform to previous studies of SCM within a municipal context: for example, a case study of the provincial Department of Economic Development, Environment and Tourism in Limpopo Province, which examined the impact of the implementation of the supply chain policy in the Department of Local Government and Housing in Limpopo Province and the practice of SCM in the Capricorn district with particular reference to Aganang Municipality. Also, it supports evidence in the 2014 SCM first review, which highlighted the many challenges faced by the implementation of SCM and the fact that the strategic objectives were also pronounced in parliament in 2014. It should be reiterated that the lack of proper SCM processes and procedures are the root cause of problems in service delivery in South Africa. 


\section{References}

1. Ambe, I.M. and Badenhorst-Weiss, J.A. (2012). Supply chain management challenges in the South African public sector, African Journal of Business Management, 6 (44), pp. 11003-11014.

2. Agus, A. (2011). The structural influence of supply chain management on product quality and business performance, International Journal of Trade, Economics and Finance, 2 (4).

3. Arlbjørn, J.S., Freytag, P.V. and De Haas, H. (2011). Service supply chain management: a survey of lean application in the municipal sector, International Journal of Physical Distribution \& Logistics Management, 41 (3), pp. 277-295.

4. Auditor General South Africa. (2012). The Municipal Report 2011/2012. Available at: http://www.auditorgeneral.co.za. Accessed on 2 July 2014.

5. Chopra, S. and Meindl, P. (2013). Supply chain management: strategy, planning and operations. $4^{\text {th }}$ ed. Upper Saddle River, NJ: Prentice Hall.

6. Council of Supply Chain Management Professionals (CSCMP). (2007). Available at: http://www.cscmp.org. Accessed on 21 January 2016.

7. Hugo, W.M.J., Badenhorst-Weiss, J.A. and Van Biljon, E.H.B. (2006). Purchasing and Supply management. Pretoria: Van Schaik.

8. Institution for Supply Chain Management. (2014). Available at: http://wwwioscm.com. Accessed on 17 August 2015.

9. Mkhize, Z.L. (2004). Transforming the government procurement system, Supply Chain Management Conference, Durban, Republic of South Africa: 22-23 November.

10. Mnguni, N. (2012). To investigate and evaluate the implementation of the supply chain management in service delivery with specific focus on procurement processes of goods and services in the head office of the Eastern Cape Department of Health. Nelson Mandela Metropolitan University: Faculty of Business and Economic Sciences.

11. Lambert, D.L. (2006). Supply chain management: processes, partnerships, performance. $2^{\text {nd }}$ ed. Florida: Hartley Press.

12. National Treasury. (2007). Republic of South Africa. Practice note number SCM 8 of 2007/2008. Available at: http://www.treasury.gov.za. Accessed on 18 February 2016.

13. National Treasury. (2005). Republic of South Africa. Elements of supply chain management. Available at: http://www.treasury.gov.za. Accessed on 14 February 2016.

14. National Treasury. (2003). Republic of South Africa. Policy Strategy to guide uniformity in procurement reform processes in government. Available at: http://www.treasury.gov.za. Accessed on 26 February 2015.

15. Naude, M.J. and Badenhorst-Weiss, J.A. (2011). The Effect of Problems on Supply Chain Wide Efficiency, Journal of Transport and Supply Chain Management, 5 (1), pp. 278-298.

16. Ngobeni, S. (2011). An analysis of the tender process in national government in South Africa. MBA Thesis, NorthWest University, Potchefstroom Campus. Available at: http//dspace.nwu.ac.za. Accessed on 3 December 2015.

17. Peng, P., Lawrence, V., Snyder, B, Lim, A. and Liu, Z. (2011). Reliable logistics networks design with facility disruptions. Available at: http://citeseerx.ist.psu.edu. Accessed on 23 December 2015.

18. Quinlan, C. (2011). Business research methods. Andover, Hampshire, UK: South-Western Cengage Learning.

19. West, M.A. (2016). The psychology of meditation. Research \& practice. $1^{\text {st }}$ ed. Great Claredon Street. United Kingdom: Oxford University Press. 